\title{
The effects of a biocide and a surfactant on the detachment of Pseudomonas fluorescens from glass surfaces
}

\author{
Manuel Simões*, Lúcia C. Simões, Sara Cleto, Maria O. Pereira, Maria J. Vieira \\ Centro de Engenharia Biológica, Universidade do Minho, 4710-057 Braga, Portugal
}

Received 16 July 2007; received in revised form 8 November 2007; accepted 9 November 2007

\begin{abstract}
Application of antimicrobial chemicals is a general procedure in the cleaning and disinfection of food-contacting surfaces. Adhesion to glass surfaces and chemically induced detachment of Pseudomonas fluorescens ATCC $13525^{\mathrm{T}}$ were studied in situ, under flow conditions, in a wellcontrolled parallel plate flow chamber (PPFC). Ortho-phthalaldehyde (OPA) and cetyltrimethyl ammonium bromide (CTAB) were applied separately, at several concentrations, to attached bacteria and their subsequent detachment was monitored. Following treatments the remaining adhered bacteria were characterized in terms of viability and cell size. Simultaneously, the planktonic cell surface was characterized in order to correlate PPFC results with thermodynamic approaches for adhesion evaluation, and surface free energy of chemically treated cells with adhesion strength. About $2.8 \times 10^{6}$ cells $/ \mathrm{cm}^{2}$ adhered to the glass surface after $30 \mathrm{~min}$ of bacterial flow, although thermodynamic analyses evidenced unfavourable adhesion. The independent application of OPA and CTAB promoted bacterial detachment to a small extent (16\% of total cells). The remaining adhering bacteria were totally non-viable for OPA $\geq 0.75 \mathrm{mM}$ and $\mathrm{CTAB} \geq 0.25 \mathrm{mM}$, showing a lack of correlation between bacterial viability and detachment. The cellular size decreased as attachment proceeded and with chemical treatment. Both chemicals altered the cell surface properties, increasing the cell-glass adhesion strength, and promoting the emergence of polar characteristics. The overall results emphasize that OPA and CTAB were markedly ineffective in removing glass-attached P. fluorescens, demonstrating that bacteria can be non-viable but remain strongly attached to the adhesion surface.
\end{abstract}

(C) 2007 Elsevier B.V. All rights reserved.

Keywords: Biofilms; Cetyltrimethyl ammonium bromide; Detachment; Disinfection; Ortho-phthalaldehyde; Pseudomonas fluorescens

\section{Introduction}

In the majority of ecosystems, microbial cells grow on surfaces, with the formation of highly structured sessile microbial communities, called biofilms (Bakker et al., 2002; Bremer et al., 2006). The development of a biofilm is believed to occur in a sequential process that involves movement of microorganisms towards surfaces, initial microbial attachment, formation of microcolonies, extracellular polymeric substances production, and biofilm maturation (Bryers, 2000; Sauer and Camper, 2001). To inhibit biofilm formation, it is necessary to prevent the initial adhesion of microorganisms (Busscher et al., 1990).

In a food processing line, the formation of biological deposits on processing equipment must be controlled (Lecrigny-Nolf et

\footnotetext{
* Corresponding author. Tel.: +351 253 604404; fax: +351 253678986 .

E-mail address: mjvsimoes@deb.uminho.pt (M. Simões).
}

al., 2000; Rossoni and Gaylarde, 2000). Microbial growth can be limited by good sanitation practices (Maukonen et al., 2003; Simões et al., 2005b; Meyer, 2006). Control of microbial attachment can facilitate disinfection (Meyer, 2003). The mechanism by which a chemical agent interacts with adhered cells has not been elucidated. The velocity of fluids on surfaces where bacterial attachment occurs, and the conditions of application of the chemicals both may affect attachment (Simões et al., 2003). Bacteria can adapt rapidly to hydrodynamic and chemical stresses (Suci et al., 1998), so it is likely that cells undergo complex physiological changes during the process of attachment of planktonic cells (Sauer and Camper, 2001). Those changes significantly reduce the susceptibility of cells to measures for their control (Cloete et al., 1997; Gilbert et al., 2002).

There is a lack of information about the behavior of cells in the earlier stages of biofilm development. The initial adhesion of a bacterium to a surface is a complicated process that is 
affected by various physicochemical properties of both the cell and the surface (Gallardo-Moreno et al., 2002a,b). The cell surface hydrophobicity is considered to be the most important physicochemical parameter controlling adhesion and detachment from surfaces (Razatos et al., 1998; Gallardo-Moreno et al., 2002a).

In this study the adhesion to glass surfaces and detachment rate of Pseudomonas fluorescens, after the application of a nonoxidising aldehyde-based biocide and a cationic surfactant were monitored in situ, under flow conditions in a parallel plate flow chamber. The relevance of cell surface properties and viability in the detachment process were also studied.

\section{Materials and methods}

\subsection{Microorganism and culture conditions}

P. fluorescens ATCC $13525^{\mathrm{T}}$ was used throughout this study. A continuous culture was grown in a 21 glass chemostat, at $27{ }^{\circ} \mathrm{C}$, with an air flow rate of $7.08 \times 10^{-3} \mathrm{l} / \mathrm{s}$. The chemostat was continuously fed with $40 \mathrm{ml} / \mathrm{h}$ of sterile medium containing glucose, $5 \mathrm{~g} / 1$, peptone, $2.5 \mathrm{~g} / 1$, and yeast extract, $1.25 \mathrm{~g} / 1$ in $0.02 \mathrm{M}$ phosphate buffer $\left(\mathrm{KH}_{2} \mathrm{PO}_{4} ; \mathrm{Na}_{2} \mathrm{HPO}_{4}\right)$ at $\mathrm{pH} 7.0 \pm 0.2$.

To perform the attachment and detachment experiments, the bacterial suspensions were prepared by aseptically removing $130 \pm 5 \mathrm{ml}$ of $P$. fluorescens culture from the chemostat, centrifuging the portion of culture at $3777 \mathrm{~g}$ for $5 \mathrm{~min}$ at $4{ }^{\circ} \mathrm{C}$; washing the pelleted cells twice with sterile $0.05 \mathrm{M}$ citrate buffer ( $\mathrm{pH} \mathrm{6)}$, and resuspending the cells in citrate buffer to obtain a bacterial suspension at $6 \times 10^{6}$ cells $/ \mathrm{ml}$.

\subsection{Chemicals tested}

The chemical agents used were a non-oxidising aldehydebased biocide, ortho-phthalaldehyde, (OPA; Sigma, Lisbon, Portugal), used at concentrations of $0.15,0.375,0.75$ and $3.75 \mathrm{mM}$; and a cationic surfactant, cetyltrimethyl ammonium bromide (CTAB; Merck, Lisbon, Portugal) used at concentrations of $0.125,0.25,0.5$ and $0.9 \mathrm{mM}$.

\subsection{Attachment and detachment monitoring}

A parallel plate flow chamber (PPFC), previously described by Sjollema et al. (1989) was used. The PPFC consisted of a nickel-coated frame measuring $16 \times 8 \times 1.8 \mathrm{~cm}$. The bottom and top $5.5 \times 3.8 \mathrm{~cm}$ plates were made of glass. These were cleaned by $50 \%$ maximum amplitude sonication using an ultrasonic processor (Cole-Parmer Instruments, Illinois, USA), for $3 \mathrm{~min}$, in a solution of commercial detergent (Sonasol Pril, Henkel Ibérica S. A., Portugal). After the sonication treatment, plates were rinsed with ultrapure water. A Teflon spacer was placed between the plates, to separate them by $0.06 \mathrm{~cm}$. The PPFC device was mounted in an inverted microscope (Diaphot 300; Nikon, Badhoevedorp, The Netherlands). The images were acquired in a CCD camera (AVC, D5CE; Sony, Tokio, Japan) connected to the microscope, and coupled to an image analyser (Image Proplus 3.0; Media Cybernetics, Bethesda, Maryland,
USA). The images were examined according to the procedure described by Azeredo et al. (1997).

To assess the rate of $P$. fluorescens attachment to glass, a cell suspension was circulated through the PPFC at $0.11 \mathrm{ml} / \mathrm{s}$ for $30 \mathrm{~min}$. Then, citrate buffer was circulated through the equipment to remove unattached and weakly adhering cells. After $30 \mathrm{~min}$, the buffer was replaced by chemicals solutions flowing at the same rate. Images were recorded every $20 \mathrm{~s}$, using an image analyser (Image Proplus 3.0; Media Cybernetics), and the data obtained were expressed as number of cells per $\mathrm{cm}^{2}$.

\subsection{Epifluorescence microscopy analysis}

After each PPFC experiment, the bacteria that remained adhering to the glass surfaces were stained with Live/Dead BacLight bacterial viability kit (Molecular Probes, Leiden, The Netherlands), according to the procedure described by Simões et al. (2005a). A microscope (AXIOSKOP; Zeiss, Göttingen, Germany), fitted with fluorescence illumination and a $100 \times$ oil immersion fluorescence objective, was used to visualise the stained cells. The optical filter combination consisted of a 480 to $500 \mathrm{~nm}$ excitation filter, in combination with a $485 \mathrm{~nm}$ emission filter. Bacterial observations were recorded as micrographs obtained using a microscope camera (AxioCam HRC; Zeiss). A program path (Scan Pro 5; Sigma), involving object measurement and data output, was used to quantify the number of cells and to measure the equivalent cell radius, as an estimate of cellular size (Walker et al., 2005). The average equivalent spherical radius of the adhered cells was determined from the cell length and width measurement assuming a uniform distribution of bacterial cell morphologies.

The mean number of cells was determined from counts of a minimum of 20 microscopic fields for each glass surface.

\subsection{Contact angles measurements, hydrophobicity and free energy of adhesion}

Bacterial hydrophobicity was evaluated from contact angle measurements, and by the method of van Oss et al. (1987, 1988, 1989). With this method, the degree of hydrophobicity of a given material is expressed as the free energy of interaction between two entities of that material immersed in water$\left(\Delta G_{\text {iwi }} \mathrm{mJ} / \mathrm{m}^{2}\right)$. If the interaction between the two entities is stronger than the interaction of each entity with water $\left(\Delta G_{\text {iwi }}<0\right)$, the material is considered hydrophobic. Conversely, if $\Delta G_{\text {iwi }}>0$, the material is hydrophilic. $\Delta G_{\text {iwi }}$ can be calculated from the surface tension components of the interacting entities, according to the equation

$$
\begin{aligned}
\Delta G_{\mathrm{iwi}}= & -2\left(\sqrt{\gamma_{\mathrm{i}}^{\mathrm{LW}}}-\sqrt{\gamma_{\mathrm{w}}^{\mathrm{LW}}}\right)^{2} \\
& +4\left(\sqrt{\gamma_{\mathrm{i}}^{+} \gamma_{\mathrm{w}}^{-}}+\sqrt{\gamma_{\mathrm{i}}^{-} \gamma_{\mathrm{w}}^{+}}-\sqrt{\gamma_{\mathrm{i}}^{+} \gamma_{\mathrm{i}}^{-}}-\sqrt{\gamma_{\mathrm{w}}^{+} \gamma_{\mathrm{w}}^{-}}\right)
\end{aligned}
$$

where $\gamma^{\mathrm{LW}}$ accounts for the Lifshitz-van der Waals component of the surface free energy and $\gamma^{+}$and $\gamma^{-}$are the electron 
acceptor and electron donor parameters, respectively, of the Lewis acid-base component $\left(\gamma^{\mathrm{AB}}\right)$, with $\gamma^{\mathrm{AB}}=2 \sqrt{\gamma^{+} \gamma^{-}}$.

The surface tension components of a solid material are obtained by measuring the angles of contact with three pure liquids. The liquids used are $\alpha$-bromonaphthalene, which is apolar, and two polar liquids, water and formamide. All these liquids have known surface tension components. The surface tension components are estimated by the simultaneous resolution of three equations of the type

$(1+\cos \theta) \gamma_{i}^{\mathrm{Tot}}=2\left(\sqrt{\gamma_{\mathrm{s}}^{\mathrm{LW}} \gamma_{\mathrm{i}}^{\mathrm{LW}}}+\sqrt{\gamma_{\mathrm{s}}^{+} \gamma_{\mathrm{i}}^{-}}+\sqrt{\gamma_{\mathrm{s}}^{-} \gamma_{\mathrm{i}}^{+}}\right)$

where $\theta$ is the contact angle and $\gamma^{\mathrm{Tot}}=\gamma^{\mathrm{LW}}+\gamma^{\mathrm{AB}}$.

When studying the interaction (free energy of adhesion) between substances $i$ and I that are immersed or dissolved in water, the total interaction energy, $\Delta G_{\mathrm{iwI}}^{\text {Tot }}$, can be expressed as

$$
\begin{aligned}
\Delta G_{\mathrm{iwI}}^{\mathrm{Tot}}= & \gamma_{\mathrm{iI}}^{\mathrm{LW}}-\gamma_{\mathrm{iw}}^{\mathrm{LW}}-\gamma_{\mathrm{Iw}}^{\mathrm{LW}} \\
& +2\left\lfloor\sqrt{\gamma_{\mathrm{w}}^{+}}\left(\sqrt{\gamma_{\mathrm{i}}^{-}}+\sqrt{\gamma_{\mathrm{I}}^{-}}+\sqrt{\gamma_{\mathrm{w}}^{-}}\right)\right. \\
& \left.+\sqrt{\gamma_{\mathrm{w}}^{-}}\left(\sqrt{\gamma_{\mathrm{i}}^{+}}+\sqrt{\gamma_{\mathrm{I}}^{+}}-\sqrt{\gamma_{\mathrm{w}}^{+}}\right)-\sqrt{\gamma_{\mathrm{i}}^{+} \gamma_{\mathrm{I}}^{-}}-\sqrt{\gamma_{\mathrm{i}}^{-} \gamma_{\mathrm{I}}^{+}}\right\rfloor
\end{aligned}
$$

Thermodynamically, if $\Delta G_{\mathrm{iwI}}^{\mathrm{Tot}}<0$ adhesion is favoured, while adhesion is not expected to occur if $\Delta G_{\mathrm{iwI}}^{\mathrm{Tot}}>0 \mathrm{~mJ} / \mathrm{m}^{2}$.

$P$. fluorescens suspensions, prepared as described for the PPFC experiments, were exposed to either OPA or CTAB solutions. Afterwards, lawns of $P$. fluorescens were prepared as described by Busscher et al. (1984), to ascertain the bacterial surface properties. Untreated cells were always used as control experiments.

The glass plates were prepared for surface characterization by immersion in a solution of the commercial detergent in ultrapure water for $30 \mathrm{~min}$. After rising with ultrapure water the glass plates were dried at $65 \pm 5^{\circ} \mathrm{C}$ for $3 \mathrm{~h}$.

The contact angles and surface tension of the untreated and treated bacteria, and the glass plates, were determined by the sessile drop contact angle measurements, using an apparatus (model OCA 15 Plus; DATAPHYSICS, Filderstadt, Germany) that allowed image acquisition and data analysis. These measurements were carried out at $25 \pm 2{ }^{\circ} \mathrm{C}$ using water, formamide and $\alpha$-bromonaphthalene (Sigma), as reference liquids. The surface tension components of the reference liquids were taken from literature (Janczuk et al., 1993). Contact angle data were obtained from at least 25 determinations for each liquid and for each experiment.

\subsection{Statistical analysis}

The data were analysed using the statistical program Statistical Package for the Social Sciences (SPSS), version 14.0. The means and standard deviations within samples were calculated for all cases. Paired $t$-test analyses were performed for PPFC results. Hydrophobicity and free energy of adhesion data were analysed by the Wilcoxon test. Statistical calculations were based on confidence level equal or higher than $95 \%$.

\section{Results}

\subsection{Microbial adhesion}

The analysis of $P$. fluorescens adhesion (Fig. 1) shows the existence of three distinct adhesion rates. During the first $300 \mathrm{~s}$ the rate was only $1 \mathrm{cell} / \mathrm{s} / \mathrm{cm}^{2}$ (linear correlation $-R^{2}=0.827$ ). Between 301 and $1000 \mathrm{~s}$ the rate was 600 cells $/ \mathrm{s} / \mathrm{cm}^{2}$ (linear correlation $\left.-R^{2}=0.978\right)$. Between 1001 and $1800 \mathrm{~s}$ the rate was about 2950 cells $/ \mathrm{s} / \mathrm{cm}^{2}$ (linear correlation $-R^{2}=0.960$ ). The final numbers of attached bacteria were $2.80 \times 10^{6}$ cells $/ \mathrm{cm}^{2}$. The duration of the experiments was found to be enough for cells to adhere strongly, as during the $30 \mathrm{~min}$ of buffer circulation, no significant decrease $(P>0.05)$ in the number of attached cells was observed.

\subsection{Effects of $O P A$ and $C T A B$ on detachment}

The $30 \mathrm{~min}$ applications of various concentrations of OPA (Fig. 2a) and CTAB (Fig. 2b) to attached P. fluorescens resulted in small reductions in the numbers of attached cells. Circulation of citrate buffer instead of OPA or CTAB solutions resulted in detachment $<1 \%$ of adhering cells. With OPA solutions, a maximum of $12.9 \%$ of the attached cells, were removed. OPA at concentrations of $0.15,0.375,0.75$ and $3.75 \mathrm{mM}$ gave detachment rates of $89,117,83$ and 200 cells $/ \mathrm{s} / \mathrm{cm}^{2}$, respectively. With CTAB solutions, a maximum of $15.8 \%$ of the cells was detached. CTAB at concentrations of $0.125,0.25$, 0.5 and $0.9 \mathrm{mM}$ gave detachment rates of 206, 244, 161 and 150 cells $/ \mathrm{s} / \mathrm{cm}^{2}$, respectively.

\subsection{Characterization of the attached bacteria}

The lengths of attached and planktonic cells were $0.840 \pm$ 0.061 and $1.16 \pm 0.11 \mu \mathrm{m}$, respectively. The difference in the mean lengths was significant $(P<0.05)$. The application of OPA or CTAB to adhering $P$. fluorescens reduced both cell size and viability (Fig. 3). With 0.75 and $3.75 \mathrm{mM}$ OPA or 0.5 and 0.9 mM CTAB cells were non-viable. With CTAB but not OPA, cell size reduction was concentration dependent $(P<0.05)$.

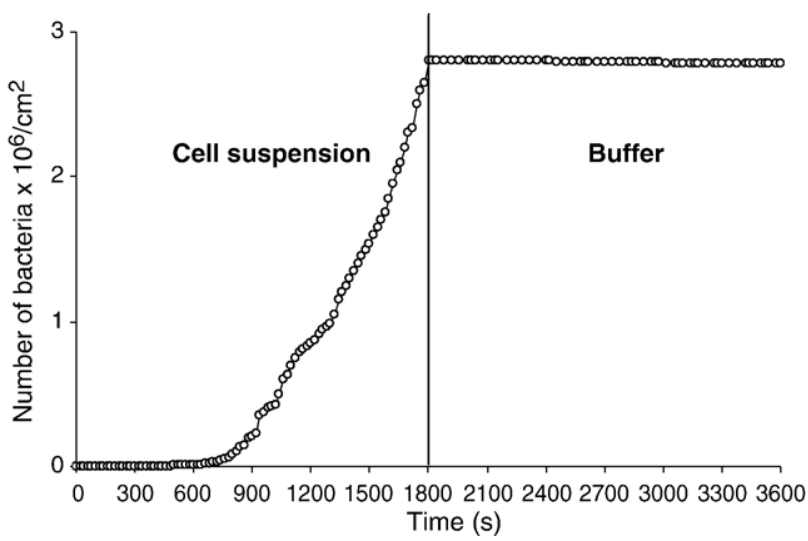

Fig. 1. P. fluorescens attached to glass during circulation of a suspension of the microorganism and subsequent circulation of citrate buffer. 


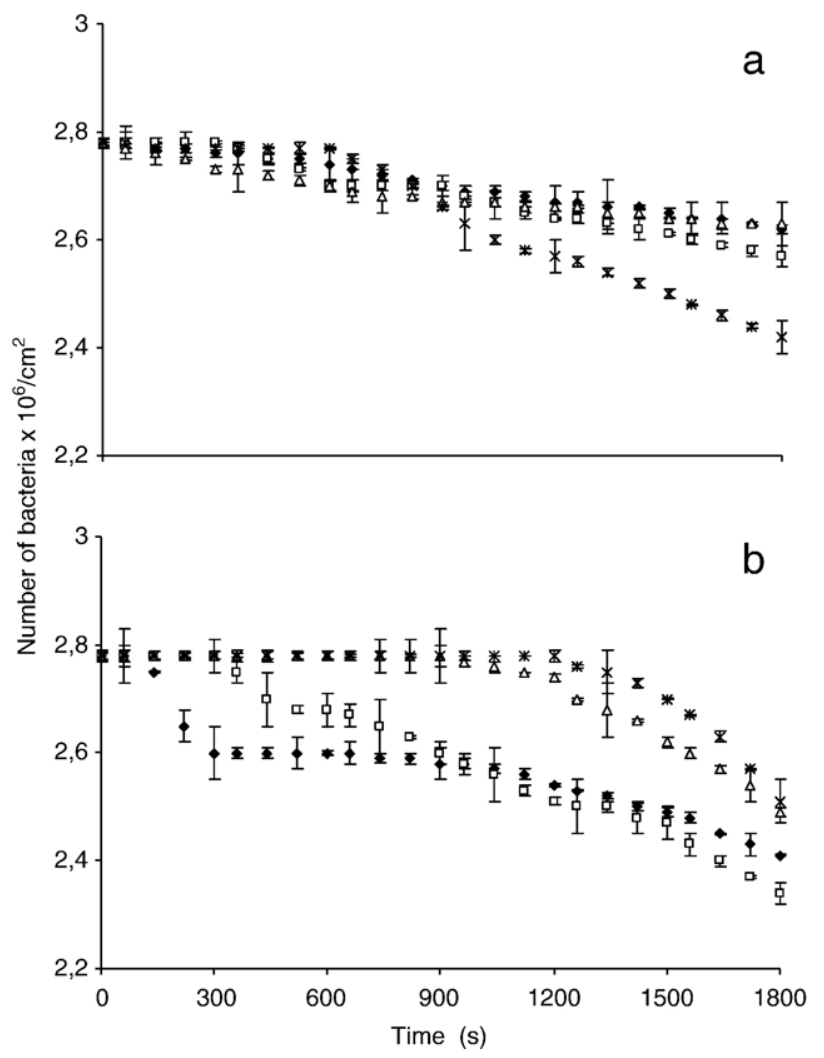

Fig. 2. P. fluorescens detachment from glass surface during treatment with (a) OPA at $0.150 \mathrm{mM}(\diamond) ; 0.375 \mathrm{mM}(\square) ; 0.750 \mathrm{mM}(\triangle) ; 3.75 \mathrm{mM}(\boldsymbol{*})$ or (b) CTAB at $0.125 \mathrm{mM}(\diamond) ; 0.250 \mathrm{mM}(\square) ; 0.500 \mathrm{mM}(\triangle) ; 0.900 \mathrm{mM}(\boldsymbol{*})$. Each symbol indicates the mean $\pm \mathrm{SD}$ of three independent experiments.

\subsection{Bacterial surface properties and free energy of adhesion}

P. fluorescens cells had hydrophilic properties $\left(\Delta G_{\mathrm{bwb}}^{\mathrm{Tot}}>\right.$ $0 \mathrm{~mJ} / \mathrm{m}^{2}$ ). The free energy of adhesion of $P$. fluorescens to glass was about $29.8 \mathrm{~mJ} / \mathrm{m}^{2}$, revealing that adhesion was not thermodynamically favoured. The application of OPA to $P$. fluorescens reduced the surface hydrophilic characteristics (Table 1), particularly at the lowest concentration tested. For other OPA concentrations the surface cellular changes were similar $(P>0.05)$. The values of the surface tension components demonstrated that bacteria developed polar properties after OPA treatment, as evidenced by the increases in $\gamma^{\mathrm{AB}}$ values. OPA decreased cellular electron donation $\left(\nabla^{-}\right)$ability and increased the electron accepting $\left(\gamma^{+}\right)$properties. This effect was not concentration dependent $(P>0.05)$. The apolar component $\left(\gamma^{\mathrm{LW}}\right)$ of bacteria was almost unaffected by OPA except at a concentration of $0.15 \mathrm{mM}(P>0.05)$. The analysis of the free energy of adhesion of OPA treated bacteria indicated an increase in the adhesion potential. The decreases in the free energy of adhesion for all the concentrations tested were not significantly different $(P>0.05)$.

Cell surface hydrophilic characteristics were progressively reduced with increasing $\mathrm{CTAB}$ concentrations (Table 1). With $0.9 \mathrm{mM}$ CTAB, bacterial surface properties changed from hydrophilic to hydrophobic $\left(\Delta G_{\mathrm{bwb}}^{\text {Tot }}<0 \mathrm{~mJ} / \mathrm{m}^{2}\right)$. The decreases of the bacterial apolar characteristics $\left(\vee^{\mathrm{LW}}\right)$ for all $\mathrm{CTAB}$ concentrations tested were not significantly different $(P>0.05)$. Polar characteristics $\left(\mho^{\mathrm{AB}}\right)$, increased significantly $(P<0.05)$ with increasing $\mathrm{CTAB}$ concentration. Lower CTAB concentrations increased, but higher concentrations decreased $\gamma^{-}$values significantly $(P<0.05)$. The $\gamma^{+}$values for cells increased significantly $(P<0.05)$ with increasing $\mathrm{CTAB}$ concentration. The thermodynamic evaluation of adhesion indicated that adhesion was not favourable when cells were treated with $0.125,0.25 \mathrm{mM}$ or $0.5 \mathrm{mM} \mathrm{CTAB}\left(\Delta G_{\mathrm{bws}}^{\mathrm{Tot}}>0 \mathrm{~mJ} / \mathrm{m}^{2}\right)$ even though the free energy of adhesion decreased with increasing CTAB concentration.

\section{Discussion}

Explanations of the adhesion of microorganisms to solid surfaces assume that the interfacial free-energy is the controlling force in cell adhesion. According to this concept, cell adhesion is favoured when the interfacial tension between the surface, the microorganism and the suspending liquid is reduced (Simões et al., 2007a). Moreover, the cell attachment has been shown to increase with increasing surface hydrophobicity (Oliveira et al., 2001). In a flowing system, microorganisms are transported to the surface by diffusion, convection, sedimentation and active movement (Gottenbos et al., 1999), and will tend to adsorb irreversibly to minimize the free energy of the system. In this study, adhesion data demonstrated that the rate of attachment

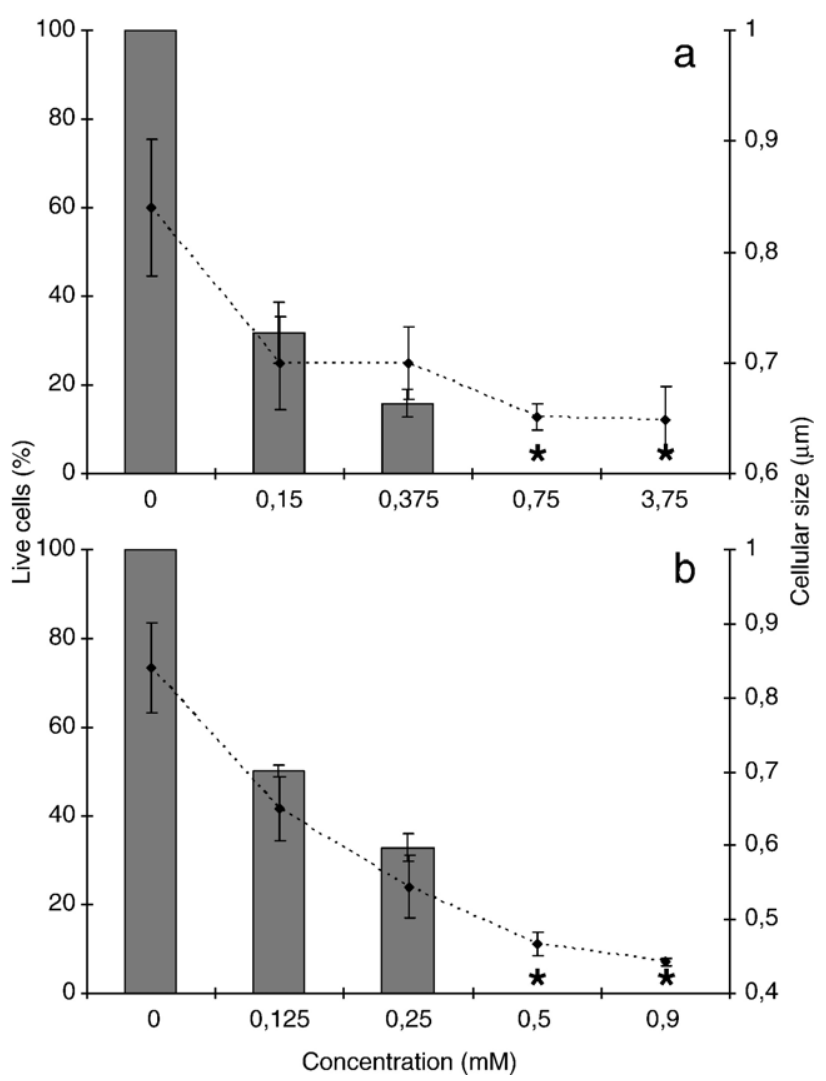

Fig. 3. Viability ( $\square$ ) and size (- -) of adhering cells treated with (a) OPA or (b) CTAB (b). * - indicates that all the cells were non-viable. Each symbol indicates the mean $\pm \mathrm{SD}$ of three independent experiments. 
Table 1

Values for the means \pm standard deviation for the hydrophobicity $\left(\Delta G_{\mathrm{bwb}}^{\mathrm{Tot}}\right)$, apolar $\left(\mathrm{\gamma}^{\mathrm{LW}}\right)$ and polar $\left(\gamma^{\mathrm{AB}}-\gamma^{-}\right.$electron donor and $\gamma^{+}$electron acceptor of the $\chi^{\mathrm{AB}}$ component) components of the surface tension of untreated bacteria and OPA or CTAB treated cells, and the free energy of adhesion ( $\left.\Delta G_{\mathrm{bws}}^{\text {Tot }}\right)$ between $P$. fluorescens (b) and glass (s) when immersed in water (w)

\begin{tabular}{|c|c|c|c|c|c|c|c|c|c|}
\hline & \multirow{2}{*}{$\begin{array}{l}\text { Without } \\
\text { treatment }\end{array}$} & \multicolumn{4}{|l|}{ [OPA] mM } & \multicolumn{4}{|c|}{ [CTAB] Mm } \\
\hline & & 0.150 & 0.375 & 0.750 & 3.75 & 0.125 & 0.250 & 0.500 & 0.900 \\
\hline$\Delta G_{\mathrm{bwb}}^{\mathrm{Tot}}\left(\mathrm{mJ} / \mathrm{m}^{2}\right)$ & $65.7 \pm 4.8$ & $6.08 \pm 1.3$ & $19.8 \pm 2.1$ & $23.4 \pm 0.79$ & $24.4 \pm 2.9$ & $71.4 \pm 3.3$ & $57.9 \pm 0.88$ & $7.90 \pm 1.1$ & $-2.21 \pm 0.41$ \\
\hline$\gamma^{\mathrm{LW}}\left(\mathrm{mJ} / \mathrm{m}^{2}\right)$ & $24.1 \pm 1.1$ & $11.7 \pm 1.2$ & $23.4 \pm 1.7$ & $24.4 \pm 1.1$ & $26.2 \pm 2.1$ & $13.2 \pm 0.88$ & $13.0 \pm 0.93$ & $15.4 \pm 1.3$ & $17.4 \pm 0.87$ \\
\hline $\mathrm{V}^{\mathrm{AB}}\left(\mathrm{mJ} / \mathrm{m}^{2}\right)$ & $7.20 \pm 0.78$ & $52.3 \pm 2.1$ & $33.1 \pm 2.4$ & $31.4 \pm 3.2$ & $30.5 \pm 3.0$ & $17.4 \pm 2.7$ & $22.5 \pm 0.91$ & $33.3 \pm 0.98$ & $27.0 \pm 2.3$ \\
\hline$\gamma^{-}\left(\mathrm{mJ} / \mathrm{m}^{2}\right)$ & $74.0 \pm 2.4$ & $47.2 \pm 3.2$ & $47.8 \pm 3.0$ & $50.7 \pm 4.3$ & $51.4 \pm 2.2$ & $90.2 \pm 3.5$ & $81.2 \pm 1.9$ & $36.4 \pm 2.7$ & $23.7 \pm 0.87$ \\
\hline$\gamma^{+}\left(\mathrm{mJ} / \mathrm{m}^{2}\right)$ & $0.200 \pm 0.01$ & $14.5 \pm 0.30$ & $5.70 \pm 0.85$ & $4.90 \pm 0.09$ & $4.50 \pm 1.0$ & $0.80 \pm 0.03$ & $1.60 \pm 0.21$ & $7.60 \pm 1.3$ & $7.70 \pm 0.99$ \\
\hline$\Delta G_{\mathrm{bws}}^{\mathrm{Tot}}\left(\mathrm{mJ} / \mathrm{m}^{2}\right)$ & $29.8 \pm 0.05$ & $18.8 \pm 2.0$ & $15.3 \pm 0.11$ & $17.0 \pm 0.09$ & $17.1 \pm 1.3$ & $41.3 \pm 0.07$ & $36.9 \pm 0.06$ & $8.20 \pm 0.16$ & $-3.89 \pm 0.08$ \\
\hline
\end{tabular}

was low during the initial $300 \mathrm{~s}$. Thereafter the rate accelerated, probably because primary surface colonizers had formed a conditioning film (Gottenbos et al., 1999; Simões et al., 2007a) on which other cells could aggregate (Rickard et al., 2003). Free energy of adhesion results showed that $P$. fluorescens adhesion to glass is not favoured. However, it is known that other factors are involved in the adhesion process. Biological mechanisms, such as the presence of adhesive molecules on cell surfaces could be major factors in the process of microbial adhesion and further biofilm development (Doyle, 2000; Sauer and Camper, 2001). Moreover, microorganisms can adapt their attachment strategies to the nature of the surface (Tsibouklis et al., 1999).

The difficulty of removing $P$. fluorescens cells from glass using either $\mathrm{CTAB}$ or OPA seemed to be associated with changes to cell surface properties induced by the chemicals. According to Pasmore et al. (2002), the attraction between bacteria and the surface is expected to play an important role in the ability to remove biofilms from a surface. Moreover, decreased detachment could be influenced by electrostatic interactions, especially when cells were treated with CTAB. Azeredo et al. (2002) found that P. fluorescens treated with $0.5 \mathrm{mM}$ CTAB become positively charged, suggesting that CTAB cements the cells to, rather than removing them from the negatively charged glass surface (Azeredo and Oliveira, 2000). Other study (Pereira and Vieira, 2001), performed with glutaraldehyde (GTA), an aldehyde-based biocide similarly to OPA, revealed that $P$. fluorescens treated with $1 \mathrm{mM}$ of GTA generated unfavourable cell-glass electrostatic interactions. The application of CTAB or OPA allowed the existence of a remaining adhering pellicle that may be a source of problems, since bacterial recovery and development of resistant populations can occur (Bower and Daeschel, 1999). Furthermore, other microorganisms can adhere to the pellicle increasing the probability of pathogens survival in the process environment (Møretrø and Langsrud, 2004; Lehner et al., 2005; Simões et al., 2005b; Lapidot et al., 2006).

Inactivated $P$. fluorescens resisted detachment. According to some authors (Barton et al., 1996; Gottenbos et al., 2000, 2001; Bruinsma et al., 2001; Liu et al., 2007), bacterial growth state and viability influences the ability of cells to adhere to abiotic surfaces. Strongly attached bacteria are unable to divide and grow, so attachment correlated with loss of viability (Gottenbos et al., 2000; Liu et al., 2007). According to Sauer and Camper (2001), a switch from planktonic and sessile growth involves phenotypic changes. In this study, this phenomenon was evident even in the chemical-free assay, as cell size variation was enhanced by the stresses imposed by the chemicals.

The findings for OPA indicate that surface changes are one of the first effects of its antimicrobial action. OPA is a U.S. Food and Drug Administration (FDA) approved chemical, composed of an aromatic ring with two aldehyde groups, with broad antimicrobial activity. Its activity on Gram-negative bacteria is attributed to strong interactions with proteins which would alter cell surface properties, and with intercellular elements such as DNA (Simões et al., 2007b).

CTAB seems to act on cell functions before promoting significant surface changes, as surface properties were substantially altered by only higher concentrations. CTAB, a cationic surfactant/quaternary ammonium compound (QAC), causes cell membrane rupture by chemical reactions and electrostatic effects (Simões et al., 2006). The antimicrobial action of QAC's is attributed to their positive charge, which allows them to form electrostatic bonds with negatively charged sites on microbial cell walls (McDonnell and Russell, 1999). Those electrostatic bonds create stresses in the wall, leading to cell lysis and death. QAC's also cause cell death by protein denaturation, disruption of cell-wall permeability, and reduction of the uptake of essential nutrients (Cloete et al., 1997). It has been suggested that the primary site of action of CTAB is lipid components of the membrane with cell lysis being a secondary effect (Gilbert et al., 2002).

In conclusion, this study provides clear evidences of resistance to detachment of P. fluorescens attached to glass. Although both the antimicrobial chemicals tested interact strongly with bacteria, their application cannot be recommended for the induction of microbial detachment. The findings showed that OPA and CTAB interact with the cell surface to inactivate cells that remain strongly adhered to the surface. A layer of such dead cells may provide a surface to which other microorganisms can attach and so facilitate the process of biofilm formation.

\section{Acknowledgements}

The authors acknowledge the financial support provided by the Portuguese Foundation for Science and Technology (Project CHEMBIO - POCI/BIO/61872/2004, SFRH/BD/ 31661/2006 - Lúcia Simões and SFRH/BPD/20582/2004 Manuel Simões). 


\section{References}

Azeredo, J., Oliveira, R., 2000. The role of exopolymers in the attachment of Sphingomonas paucimobilis. Biofouling 16, 59-67.

Azeredo, J., Meinders, J., Feijó, J., Oliveira, J., 1997. Determination of cell number and size of a population of Pseudomonas fluorescens by image analysis. Biotechnology Techniques 11, 355-358.

Azeredo, J., Pacheco, A.P., Lopes, I., Oliveira, R., Vieira, M.J., 2002. Monitoring cell detachment by surfactants in a parallel plate flow chamber. Proceedings of the International Specialised Conference on Biofilm Monitoring, Porto, pp. 62-65.

Barton, A.J., Sagers, R.D., Pitt, W.G., 1996. Measurement of bacterial growth rates on polymers. Journal of Biomedical Materials Research 32, 271-278.

Bakker, D.P., Busscher, H.J., van der Mei, H.C., 2002. Bacterial deposition in a parallel plate and stagnation point flow chamber: microbial adhesion mechanisms dependent on the mass transport conditions. Microbiology 148, 597-603.

Bower, C.K., Daeschel, M.A., 1999. Resistance responses of microorganisms in food environments. International Journal of Food Microbiology $50,33-44$.

Bremer, P.J., Fillery, S., McQuillan, A.J., 2006. Laboratory scale Clean-In-Place (CIP) studies on the effectiveness of different caustic and acid wash steps on the removal of dairy biofilms. International Journal of Food Microbiology 106, 254-262.

Bruinsma, G.M., Rustema-Abbing, M., van der Mei, H.C., Busscher, H.J., 2001. Effects of cell surface damage on surface properties and adhesion of Pseudomonas aeruginosa. Journal of Microbiological Methods 45, 95-101.

Bryers, J.D., 2000. Biofilm formation and persistence. In: Bryers, J.D. (Ed.), Biofilms II: Process Analysis and Applications. Wiley-Liss, pp. 45-88.

Busscher, H.J., Weerkamp, A.H., van der Mei, H.C., Pelt, A.W.J., de Jong, H.P., Arends, J., 1984. Measurements of the surface free energy of bacterial cell surfaces and its relevance for adhesion. Applied and Environmental Microbiology 48, 980-983.

Busscher, H.J., Sjollema, J., van der Mei, H., 1990. Relative importance of surface free energy as a measure of hydrophobicity in bacterial adhesion to surfaces. In: Doyle, R.J., Rosenberg, M. (Eds.), Microbial Cell Surface Hydrophobicity. American Society for Microbiology, Washington D.C.

Cloete, T.E., Jacobs, L., Brozel, V.S., 1997. The chemical control of biofouling in industrial water systems. Biodegradation 9, 23-37.

Doyle, R.J., 2000. Contribution of the hydrophobic effect to microbial adhesion. Microbes and Infection 2, 391-400.

Gallardo-Moreno, A.M., González-Martín, M.L., Pérez-Giraldo, C., Garduño, E., Bruque, J.M., Gómez-García, A.C., 2002a. Thermodynamic analysis of growth temperature dependence in the adhesion of Candida parapsilosis to polystyrene. Applied and Environmental Microbiology 68, 2610-2613.

Gallardo-Moreno, A.M., González-Martín, M.L., Pérez-Giraldo, C., Bruque, J.M., Gómez-García, A.C., 2002b. Serum as a factor influencing adhesion of Enterococcus faecalis to glass and silicone. Applied and Environmental Microbiology 68, 5784-5787.

Gilbert, P., Allison, D.G., McBain, A.J., 2002. Biofilms in vitro and in vivo: do singular mechanisms influx cross-resistance? Journal of Applied Microbiology $92,98 \mathrm{~S}-110 \mathrm{~S}$.

Gottenbos, B., van der Mei, H.C., Busscher, H.J., 1999. Models for studying initial adhesion and surface growth in biofilm formation on surfaces. Methods in Enzymology 310, 523-533.

Gottenbos, B., van der Mei, H.C., Busscher, H.J., 2000. Initial adhesion and surface growth of Staphylococcus epidermidis and Pseudomonas aeruginosa on biomedical polymers. Journal of Biomedical Materials Research 50, 208-214.

Gottenbos, B., Grijpma, D.W., van der Mei, H.C., Feijen, J., Busscher, H.J., 2001. Antimicrobial effects of positively charged surfaces on adhering Gram-positive and Gram-negative bacteria. Journal of Antimicrobial Chemotherapy 48, 7-13.

Janczuk, B., Chibowski, E., Bruque, J.M., Kerkeb, M.L., Gonzalez-Caballero, F.J., 1993. On the consistency of surface free energy components as calculated from contact angle of different liquids: an application to the cholesterol surface. Journal of Colloid and Interface Science 159, 421-428.
Lapidot, A., Romling, U., Sima, Y., 2006. Biofilm formation and the survival of Salmonella Typhimurium on parsley. International Journal of Food Microbiology 109, 229-233.

Lecrigny-Nolf, S., Faille, C., Benezech, T., 2000. Removal kinetics of Bacillus cereus spores from a stainless steel surface exposed to constant shear stress 2. Removal kinetics modelling: Influence of adhesion conditions. Biofouling $15,299-311$.

Lehner, A., Riedel, K., Eberl, L., Breeuwer, P., Diep, B., Stephan, R., 2005. Biofilm formation, extracellular polysaccharide production, and cell-tocell signalling in various Enterobacter sakazakii strains: aspects promoting environmental persistence. Journal of Food Protection 68, 2287-2294.

Liu, Y., Strauss, J., Camesano, T.A., 2007. Thermodynamic investigation of Staphylococcus epidermidis interactions with protein-coated substrata. Langmuir 23, 7134-7142.

Maukonen, J., Mättö, J., Wirtanen, G., Raaska, L., Mattila-Sandholm, T., Saarela, M., 2003. Methodologies for the characterization of microbes in industrial environments: a review. Journal of Industrial Microbiology and Biotechnology 30, 327-356.

Meyer, B., 2003. Approaches to prevention, removal and killing of biofilms. International Biodeterioration \& Biodegradation 51, 249-253.

Meyer, B., 2006. Does microbial resistance to biocides create a hazard to food hygiene? International Journal of Food Microbiology 112, 275-279.

McDonnell, G., Russell, A.D., 1999. Antiseptics and disinfectants: activity, action, and resistance. Clinical Microbiology Reviews 12, 147-179.

Møretrø, T., Langsrud, S., 2004. Listeria monocytogenes: biofilm formation and persistence in food-processing environments. Biofilms 1, 107-121.

Oliveira, R., Azeredo, J., Teixeira, P., Fonseca, A.P., 2001. The role of hydrophobicity in bacterial adhesion. In: Gilbert, P., Allison, D., Brading, M., Verran, J., Walker, J. (Eds.), Biofilm Community and Interactions: Chance or Necessity? Bioline, Cardiff, pp. 11-22.

Pereira, M.O., Vieira, M.J., 2001. Effects of the interactions between glutaraldehyde and the polymeric matrix on the efficacy of the biocide against Pseudomonas fluorescens biofilms. Biofouling 17, 93-101.

Pasmore, M., Todd, P., Pfiefer, B., Rhodes, M., Bowman, C.N., 2002. Effect of polymeric surface properties on the reversibility of attachment of Pseudomonas aeruginosa in the early stages of biofilm development. Biofouling $18,65-71$.

Razatos, A., Ong, Y.-L., Sharma, M.M., Georgiou, G., 1998. Molecular determinants of bacterial adhesion monitored by atomic force microscopy. Proceedings of the National Academy of Sciences of the United States of America 95, 11059-11064.

Rickard, A.H., Gilbert, P., High, N.J., Kolenbrander, P.E., Handley, P.S., 2003. Bacterial coaggregation: an integral process in the development of multispecies biofilms. Trends in Microbiology 11, 94-100.

Rossoni, E.M.M., Gaylarde, C.C., 2000. Comparison of sodium hypochlorite and peracetic acid as sanitising agents for stainless steel food processing surfaces using epifluorescence microscopy. International Journal of Food Microbiology 61, 81-85.

Sauer, K., Camper, A.K., 2001. Characterization of phenotypic changes in Pseudomonas putida in response to surface-associated growth. Journal of Bacteriology 183, 6579-6589.

Simões, M., Carvalho, H., Pereira, M.O., Vieira, M.J., 2003. Studies on the behavior of Pseudomonas fluorescens biofilms after ortho-phthalaldehyde treatment. Biofouling 19, 151-157.

Simões, M., Pereira, M.O., Vieira, M.J., 2005a. Validation of respirometry as a short-term method to assess the toxic effect of a biocide. Biofouling 47 , 217-223.

Simões, M., Pereira, M.O., Vieira, M.J., 2005b. Action of a cationic surfactant on the activity and removal of bacterial biofilms formed under different flow regimes. Water Research 39, 478-486.

Simões, M., Pereira, M.O., Machado, I., Simões, L.C., Vieira, M.J., 2006. Comparative antibacterial potential of selected aldehyde-based biocides and surfactants against planktonic Pseudomonas fluorescens. Journal of Industrial Microbiology and Biotechnology 33, 741-749.

Simões, L.C., Simões, M., Oliveira, R., Vieira, M., 2007a. Potential of the adhesion of bacteria isolated from drinking water to materials. Journal of Basic Microbiology 47, 174-183. 
Simões, M., Simões, L.C., Cleto, S., Machado, I., Pereira, M.O., Vieira, M.J., 2007b. Antimicrobial mechanisms of ortho-phtalaldehyde action. Journal of Basic Microbiology 47, 230-242.

Sjollema, J., Busscher, H.J., Weerkamp, A.H., 1989. Real-time enumeration of adhering microorganisms in a parallel plate flow cell using automated image analysis. Journal of Microbiological Methods 9, 73-78.

Suci, P.A., Vrany, J.D., Mittelman, M.W., 1998. Investigation of interactions between antimicrobial agents and bacterial biofilms using attenuated total reflection Fourier transform infrared spectroscopy. Biomaterials 19, 327-339.

Tsibouklis, J., Stone, M., Thorpe, A.A., Graham, P., Peters, V., Heerlien, R., Smith, J.R., Green, K.L., Nevell, T.G., 1999. Preventing bacterial adhesion onto surfaces: the low-surface-energy approach. Biomaterials 20, $1229-1235$ van Oss, C.J., Chaudhury, M.K., Good, R.J., 1987. Monopolar surfaces. Advances in Colloid and Interface Science 28, 35-64.

van Oss, C.J., Good, R.J., Chaudhury, M.K., 1988. Additive and nonadditive surface tension components and the interpretation of contact angles. Langmuir 4, 884-891.

van Oss, C.J., Ju, L., Chaudhury, M.K., Good, R.J., 1989. Estimation of the polar parameters of the surface tension of liquids by contact angle measurements on gels. Journal of Colloid and Interface Science 128, 313-319.

Walker, L.S., Hill, J.E., Redman, J.A., Elimelech, M., 2005. Influence of growth phase on adhesion kinetics of Escherichia coli D21 g. Applied and Environmental Microbiology 71, 3093-3099. 